\title{
Post-mortem investigations on a leatherback turtle Dermochelys coriacea stranded along the Northern Adriatic coastline
}

\author{
Lisa Poppi ${ }^{1}$, Annalisa Zaccaroni ${ }^{2}$, Daniela Pasotto ${ }^{1}$, Giorgia Dotto ${ }^{1}$, \\ Federica Marcer ${ }^{3}$, Dino Scaravelli ${ }^{2}$, Sandro Mazzariol ${ }^{1, *}$ \\ ${ }^{1}$ Department of Comparative Biomedicine and Food Science, University of Padova, Viale dell'Università 16, \\ Legnaro (PD) 35020, Italy \\ ${ }^{2}$ Department of Veterinary Medical Sciences, University of Bologna, Ozzano dell'Emilia, Bologna 40064, Italy \\ ${ }^{3}$ Department of Animal Medicine, Production and Health, University of Padova, Viale dell'Università 16, \\ Legnaro (PD) 35020, Italy
}

\begin{abstract}
Leatherback sea turtles Dermochelys coriacea are regularly reported in the Mediterranean Sea but rarely reach the northern Adriatic Sea. In the summer of 2009, a well-preserved carcass of an adult female of this species was found dead along the coast of Lido di Venezia. A complete necropsy was carried out, along with evaluation of levels of tissue trace elements. The the post-mortem revealed acute severe bacterial gastroenteritis caused by Photobacterium damselae ssp. piscicida, an opportunistic agent that infected an apparently debilitated animal weakened by ingested plastic debris. High levels of heavy metals ( $\mathrm{Hg}, \mathrm{Pb}, \mathrm{Cd}$ and $\mathrm{As})$ found in the liver and kidneys might have contributed to the animal's demise. These findings support previous indications that marine debris is one of the major threats to marine animals, particularly for critically endangered species such as the leatherback turtle.
\end{abstract}

KEY WORDS: Leatherback turtle Photobacterium damselae ssp. piscicida Marine debris Adriatic Sea

\section{INTRODUCTION}

The leatherback sea turtle Dermochelys coriacea (Vandelli, 1761) is a circumglobal species with the largest distribution of all reptiles (James et al. 2005). It is listed as critically endangered in the International Union for Conservation of Nature Red List of Threatened Species (Sarti Martinez 2000) because of human impacts on its population health worldwide (Spotila et al. 1996). Besides loggerhead (Caretta caretta) and green (Chelonia mydas) turtles, which reproduce in the Mediterranean, leatherbacks are regularly present in this basin, most likely originating from Atlantic populations (Casale et al. 2003). In particular, the number of animals stranded in the Adriatic Sea, mainly in the southeastern basin, dur- ing the summer seems to be higher than the Mediterranean average (Lazar et al. 2008). They are rarely reported to reach the northern coastline. Herein, we report the main findings of a post-mortem investigation carried out on a leatherback sea turtle stranded along the northern Adriatic coastline.

\section{MATERIALS AND METHODS}

On 9 June 2009, an adult female leatherback sea turtle (total length: $178 \mathrm{~cm}$; curved carapace length: $138 \mathrm{~cm}$; mass: $199.5 \mathrm{~kg}$ ) was found dead on the sandy beach of Lido di Venezia, Venice, Italy $\left(45^{\circ} 24^{\prime} 44^{\prime \prime} \mathrm{N}\right.$, $\left.12^{\circ} 22^{\prime} 33^{\prime \prime} \mathrm{E}\right)$. The preservation status of the carcass was good, and a detailed post-mortem examination 
was performed at the Faculty of Veterinary Medicine of Padova within $24 \mathrm{~h}$ of recovery of the stranded animal. Tissue samples were preserved in $10 \%$ neutral buffered formalin for histopathological examination, refrigerated for microbiological and parasitological examinations or frozen for biomolecular and ecotoxicological investigations. For the histopathological examination, the tissues were embedded in paraffin, sectioned ( $4 \mu \mathrm{m}$ thickness) and routinely stained with hematoxylin and eosin. Selected tissue sections from the main organs were also stained using different histochemical staining techniques (Periodic acidSchiff, Gram and Giemsa staining) to detect biological agents. Danscher's auto-metallographic technique (Danscher \& Moller-Madsen 1985) and the rhodizonate method for lead salts were used on hepatic and renal tissue to detect inorganic mercury and lead particles, respectively (Lillie 1954). During necropsy, intestinal swabs were collected for standard microbiological analyses. The samples were inoculated onto sheep-blood agar (tryptic soy agar supplemented with $5 \%$ defibrinated sheep blood) and incubated aerobically at 28 and $37^{\circ} \mathrm{C}$ for 24 to $48 \mathrm{~h}$. The isolated colonies were biochemically identified using API 20NE (bioMérieux). To confirm the identity of the isolates, a molecular analysis was performed. The total DNA of the isolates was extracted by heating a selected colony at $100^{\circ} \mathrm{C}$ for $10 \mathrm{~min}$ and emulsifying in $100 \mu \mathrm{l}$ of sterile nuclease-free water; this was used as a template for further molecular investigations.

Parasitological examinations were performed on all the major organs. The collected parasites were stored in $70 \%$ ethanol and studied by light microscopy after staining with borax-carmine and clarifying in Amman's lactophenol.

Trace elements in the liver, kidney, skin and muscle tissues were analyzed at the University of Bologna, Italy. Subsamples $(0.7 \mathrm{~g})$ of each tissue were digested with a Milestone MLS 1200 Mega microwave oven using $4 \mathrm{ml}$ of nitric acid and $1 \mathrm{ml}$ of hydrogen peroxide. Measurements of the concentrations of trace elements (namely, arsenic, lead, chromium, copper, manganese, iron, selenium, zinc, cadmium, nickel and mercury), were performed by inductively coupled plasma optical emission spectrometry using a Perkin Elmer Optima 2100 DV instrument coupled with a CETAC U5000AT+ ultrasound nebulizer for mercury. Two blanks were run during each set of analysis to check for purity of the trace elements, and the accuracy of the method was verified using reference materials (lyophilized mussel; CRM 278, Community Bureau of Reference, BCR, Brussels). All of the reference material values were within the certified limits.

\section{RESULTS}

External examination revealed poor body condition and bloody discharge from the mouth and the nostrils, along with epidermal bruises. In addition, severe oedema and several petechiae in the subcutaneous tissues and the internal viscera were seen. A moderate amount of sero-hemorrhagic fluid with fibrin was found in the coelomatic cavity. Upon examination of the gastrointestinal tract, acute severe diffuse hemorrhagic gastroenteritis was observed in association with the presence of a plastic fragment perforating a fold of the gastric mucosa (Fig. 1). As reported in Table 1, 14 different foreign bodies were found in the alimentary tract, mainly represented by floating plastic fragments, obstructing the intestinal lumen (Fig. 1). Upon microscopic investigation, diffuse and severe hemorrhagic mucosal necrosis with low-grade heterophilic inflammation was observed in the esophagus, stomach and upper intestine with

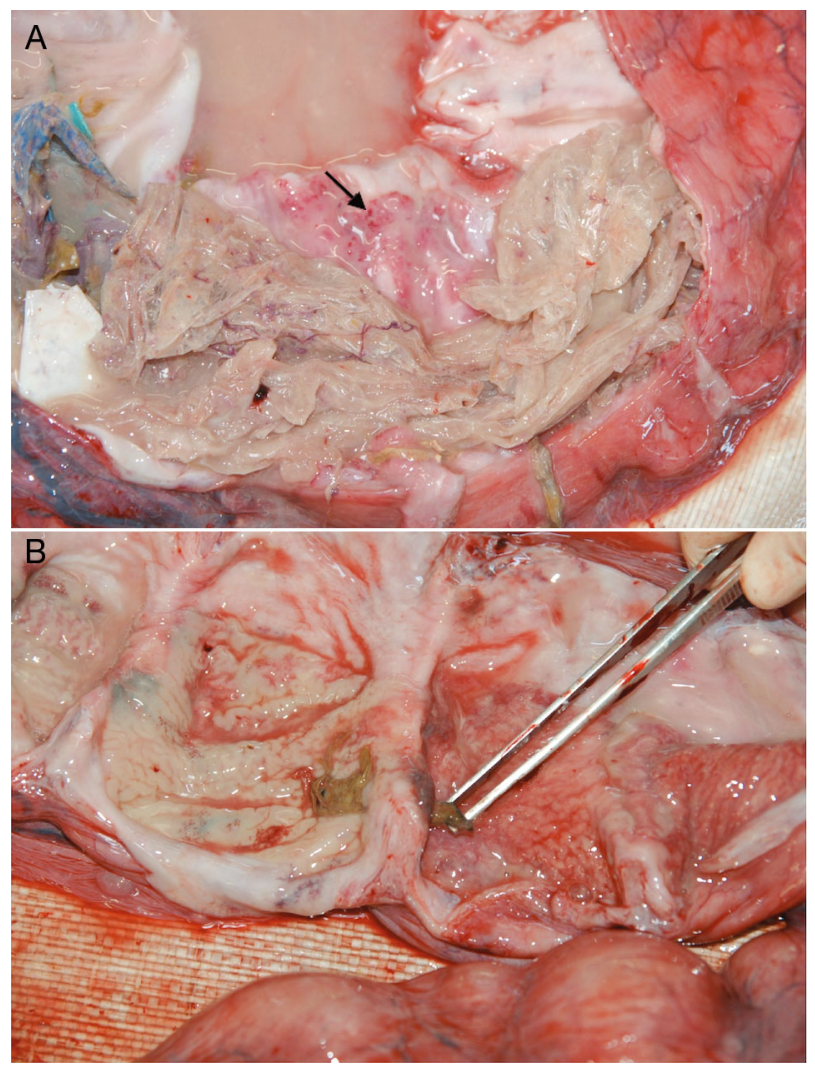

Fig. 1. Foreign bodies found during gross examination in the gastro-intestinal tract of the stranded Dermochelys coriacea. (A) Multiple pieces of plastic obstructing the intestinal lumen associated with hemorrhages, ulceration and severe diffuse edema of the enteric mucosa (arrow). (B) A rigid plastic fragment perforating the gastric wall 
multiple foci of hepatic, renal and cardiac necrosis and moderate to severe melanomacrophage hypertrophy and hyperplasia in the liver (Fig. 2). Chronic mild multifocal bronchopneumonia was diagnosed during the histopathologic examination.

The microbiological and biochemical assays identified a hemolytic strain of Photobacterium damselae. To confirm the identity of the isolate belonging to this species and to characterize its subspecies ( $P$. damselae ssp. piscicida or $P$. damselae ssp. damselae), a duplex PCR using 76a-76b and Ure5'-Ure3' primers was performed as previously described (Amagliani et al. 2009). In the reaction, a no-template control and a positive control (provided by the Istituto Zooprofilattico Sperimentale delle Venezie, Padova) were included. The duplex PCR assay confirmed the pres-

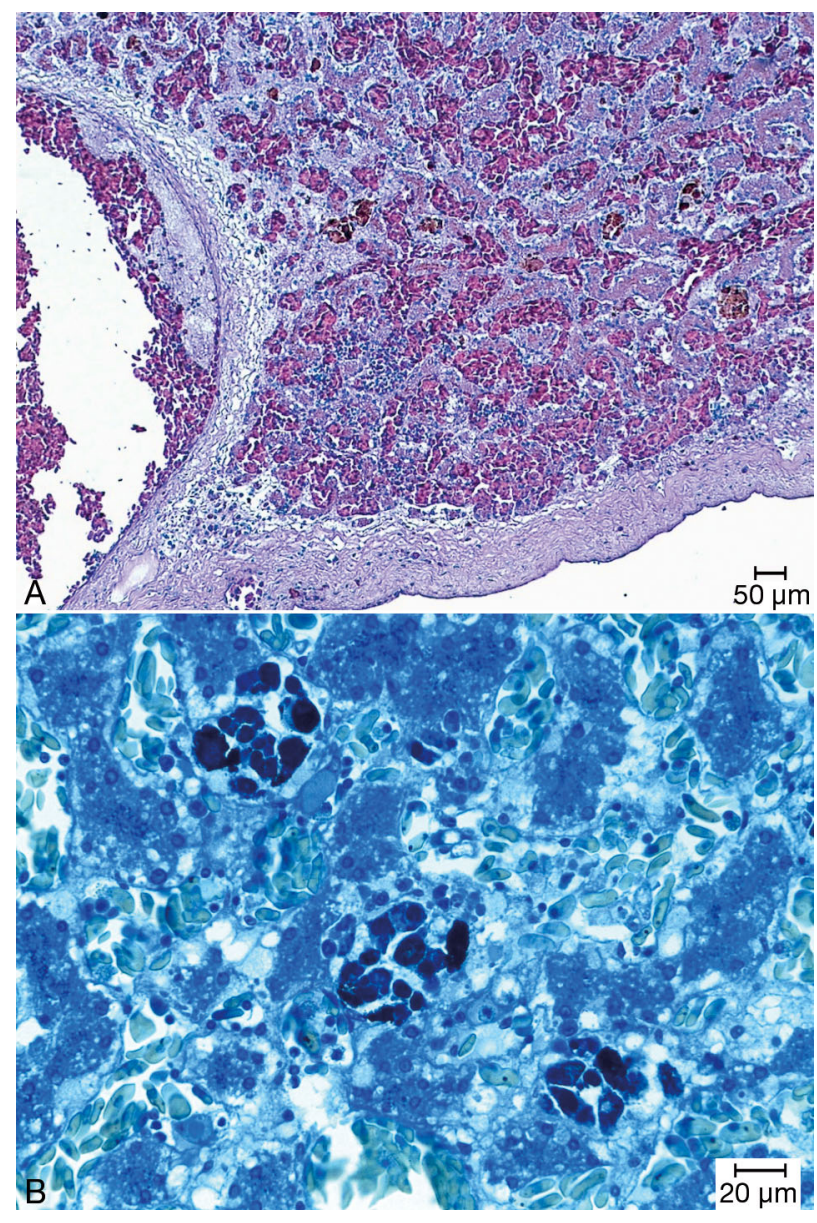

Fig. 2. Microscopic changes in melanomacrophages in the liver of the stranded Dermochelys coriacea. (A) Hyperplasia and hypertrophy in hepatic melanomacrophages are evident (hematoxylin \& eosin, 100×). (B) A histochemical technique specific to inorganic $\mathrm{Hg}$ confirms the presence of this metal in melanomacrophages, indicated by black cytoplasmic deposits (Danscher's staining, 400×) ence of $P$. damselae ssp. piscicida. Electrophoresis of the PCR products confirmed the expected amplification fragment of 297 base pairs (Fig. 3).

Twenty-three adult trematode specimens with morphological features overlapping those described by Almor et al. (1989) for Pyelosomum renicapite (Digenea; Pronocephalidae) were found in the intestine.

Toxicological examination revealed high hepatic and renal levels of $\mathrm{Hg}, \mathrm{Pb}, \mathrm{Cd}$ and $\mathrm{As}$, but extremely low levels of Fe and $\mathrm{Zn}$. The findings of the complete analysis of the trace elements are summarized in Table 2. Under microscopic observation using specific staining, $\mathrm{Hg}$ and $\mathrm{Pb}$ concentrations were mostly

Table 1. Marine debris found in the stomach of the stranded leatherback sea turtle (type and dimensions)

\begin{tabular}{|lc|}
\hline Type of marine debris & Dimensions $(\mathrm{cm})$ \\
\hline Hygienic pad & $15 \times 5$ \\
Plastic pieces & $16.5 \times 13$ \\
& $6.5 \times 12$ \\
& $21 \times 4$ \\
& $10 \times 12$ \\
$4 \times 6$ \\
Shopping bag parts & $3.5 \times 3$ \\
& $4.5 \times 2$ \\
Plastic can parts & $40 \times 20$ \\
Small rope & $20 \times 4$ \\
& $4.5 \times 3.5$ \\
& $5 \times 1.5$ \\
& 19 \\
\end{tabular}

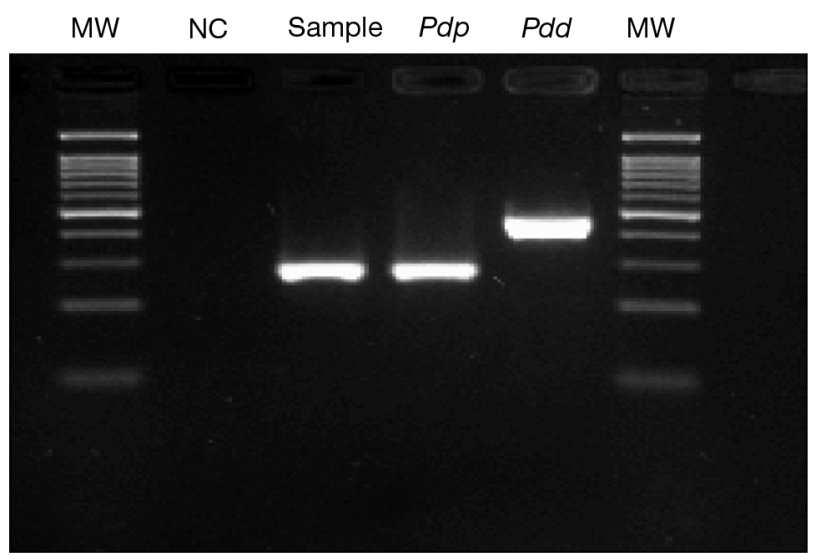

Fig. 3. Agarose gel electrophoresis of PCR amplified products. Lane MW: DNA molecular weight marker (100 bp ladder); Lane NC: no-template control; Lane sample: Photobacterium damselae ssp. piscicida (leatherback turtle isolate); Lane Pdp: P. damselae ssp. piscicida (positive control); Lane Pdd: P. damselae ssp. damselae (positive control) 
Table 2. Heavy metal concentrations ( $\mu \mathrm{g} \mathrm{g}^{-1}$ wet weight) in tissues of the stranded Dermochelys coriacea

\begin{tabular}{|lcccl|}
\hline \multirow{2}{*}{ Metal } & \multicolumn{5}{c}{ Organ } \\
\cline { 2 - 5 } & Liver & Kidney & Muscle & Skin \\
\hline $\mathrm{Co}$ & 0.5 & 0.83 & 0.32 & 0.5 \\
$\mathrm{Cr}$ & 0.95 & 0.16 & 0.13 & 0.18 \\
$\mathrm{Mn}$ & 3.75 & 0.89 & 0.2 & 0.25 \\
$\mathrm{As}$ & 2.13 & 3.75 & 11.84 & 2.65 \\
$\mathrm{Se}$ & 12.57 & 14.57 & 5.94 & 6.7 \\
$\mathrm{Cu}$ & 7.57 & 1.47 & 0.54 & 0.25 \\
$\mathrm{Zn}$ & 13.5 & 5.7 & 7.3 & 3.98 \\
$\mathrm{Fe}$ & 0.77 & 521 & 80.95 & 8.4 \\
$\mathrm{Hg}$ & 20.4 & 1.95 & 0.8 & 0.7 \\
$\mathrm{~Pb}$ & 16.37 & 8.42 & 0.13 & 0.76 \\
$\mathrm{Cd}$ & 5.68 & 40.81 & 0.26 & 0.49 \\
& & & & \\
\hline
\end{tabular}

localized in the cytoplasm of the hyperplastic melanomacrophages in the liver (Fig. 3) and in the epithelial cells of the renal tubules.

\section{DISCUSSION}

The post-mortem studies carried out on this adult specimen of Dermochelys coriacea revealed acute severe hemorrhagic gastroenteritis associated with the presence of Photobacterium damselae ssp. piscicida isolated from the intestinal tract. Based on necropsies performed on sea turtles, several studies have reported a high frequency of inflammatory changes of the alimentary tract associated with a wide range of Gram-positive and Gram-negative bacteria (Orós et al. 2004, 2005). The present study adds to the existing literature, being the first to report in a marine turtle the presence of $P$. damselae ssp. piscicida, the disease-causing agent of the bacterial septicemia in marine fishes known as pasteurellosis or pseudotubercolosis (Romalde 2002). In contrast, the subspecies damselae has been described primarily in $D$. coriacea (Obendorf et al. 1987), and is also occasionally encountered in humans (Barber \& Swygert 2000, Alvarez et al. 2006, Aigbivbalu \& Maraqa 2009, Kim et al. 2009). The necro-hemorrhagic changes observed microscopically in the gastric, intestinal, hepatic and renal tissues during the postmortem analyses suggest a pathogenic mechanism similar to that observed in fishes, where P. damselae ssp. piscicida induces the destruction of macrophages and neutrophils by the apoptogenic exotoxin AIP56 (do Vale et al. 2007). The piece of plastic found in the stomach penetrating the gastric mucosa, along with the huge amount of ingested plastic objects, could be considered predisposing factors for the infection (Bugoni et al. 2001, Orós et al. 2004, 2005). The amount of plastic fragments found in the alimentary tract appeared to present an obstacle to food passage in the lumen, possibly causing the poor body condition and likely representing the primary cause of death (Lazar \& Gracan 2011). The presence of the digenetic trematode Pyelosomum renicapite, often found in the alimentary tract of apparently healthy turtles (Threlfall 1979, Almor et al. 1989, Manfredi et al. 1996), was determined to be of little or no clinical significance.

The trace element analyses conducted on selected tissues of the stranded leatherback turtle showed elevated concentrations of toxic heavy metals (i.e. $\mathrm{Pb}$, $\mathrm{Hg}, \mathrm{Cd}$ and As) but significantly lower hepatic Fe levels compared with those indicated by (albeit scarce) existing data on Dermochelys coriacea (Davenport \& Wrench 1990, Caurant et al. 1999, Godley et al. 1999, Deem et al. 2006, Guirlet et al. 2008, Innis et al. 2010, Harris et al. 2011). The data obtained for Se, Zn, Hg, $\mathrm{Cd}$ and $\mathrm{Pb}$ concentrations were also higher than those reported for loggerhead and green sea turtles from the Mediterranean area (Andreani et al. 2008).

In particular, renal and hepatic Cd concentrations were higher than the toxic threshold established for freshwater painted turtles Chrysemys picta (Rie et al. 2005). Despite marine turtles being considered organisms that accumulate higher $\mathrm{Cd}$ concentrations (Storelli et al. 2005) than freshwater turtles and terrestrial vertebrates, it is possible that toxicity occurred in this animal. The $\mathrm{Hg}$ and Se tissue levels were high. The low molar Hg/Se ratio (0.64) suggests short-term exposure to high levels of $\mathrm{Hg}$, as longterm exposure yields a value close to 1 owing to the detoxifying action of Se (Storelli et al. 2005). The high concentrations of these heavy metals, specifically $\mathrm{Hg}$ and $\mathrm{Pb}$, might have been caused by the ingested foreign bodies. Histochemical techniques specific for $\mathrm{Hg}$ and $\mathrm{Pb}$ showed an intense staining, confirming high levels of these 2 metals in the cytoplasm of hypertrophic and hyperplastic hepatic melanomacrophages. These cells are normally encountered in reptile livers, where they are able to phagocytize erythrocytes and foreign materials (Christiansen et al. 1996), and their hyperplasia and hypertrophy are considered a nonspecific response to emaciation, stress and chronic pathological processes (Flint et al. 2009). In this case, the hyperplastic response of this cellular population might have been caused by the poor body condition of the animal.

In conclusion, the results of the post-mortem studies conducted on this adult female leatherback sea 
turtle suggest that the bacterial gastroenteritis was caused by an opportunistic agent that infected a debilitated animal weakened by the ingestion of marine debris. These observations are in accordance with previous studies on stranded turtles, which report marine debris as one of the major threats to marine animals, particularly for already-endangered species such as the leatherback sea turtle (Bugoni et al. 2001, Mrosovsky et al. 2009, Lazar \& Gracan 2011). Finally, the present study contributes to the current knowledge on the pathology and ecotoxicology of leatherback sea turtles and underlines the necessity of performing post-mortem examinations routinely on stranded animals (Flint et al. 2009).

\section{LITERATURE CITED}

Aigbivbalu L, Maraqa N (2009) Photobacterium damsela wound infection in a 14-year-old surfer. South Med J 102:425-426

Almor P, Raga JA, Abril E, Balbuena JA, Duguy R (1989) Parasitisme de la Tortue Luth, Dermochelys coriacea (Linnaeus, 1766) dans les eaux europeennes par Pyelosomum renicapite (Leidy, 1856). Vie Milieu 39:57-59

Alvarez JR, Lamba S, Dyer KY, Apuzzio JJ (2006) An unusual case of urinary tract infection in a pregnant woman with Photobacterium damselae. Infect Dis Obstet Gynecol 2006:80682

Amagliani G, Omiccioli E, Andreoni F, Boiani R and others (2009) Development of a multiplex PCR assay for Photobacterium damselae subsp. piscicida identification in fish samples. J Fish Dis 32:645-653

Andreani G, Santoro M, Cottignoli S, Fabbri M, Carpenè E, Isani G (2008) Metal distribution and metallothionein in loggerhead (Caretta caretta) and green (Chelonia mydas) sea turtles. Sci Total Environ 390:287-294

Barber GR, Swygert JS (2000) Necrotizing fasciitis due to Photobacterium damsela in a man lashed by a stingray. N Engl J Med 342:824

Bugoni L, Krause L, Petry MV (2001) Marine debris and human impacts on sea turtles in southern Brazil. Mar Pollut Bull 42:1330-1334

Casale P, Nicolosi P, Freggi D, Turchetto M, Argano R (2003) Leatherback turtles (Dermochelys coriacea) in Italy and in the Mediterranean basin. Herpetol J 13:135-139

> Caurant F, Bustamante P, Bordes M, Miramand P (1999) Bioaccumulaton of cadmium, copper and zinc in some tissues of three species of marine turtles stranded along the French Atlantic coasts. Mar Pollut Bull 38: 1085-1091

> Christiansen JL, Grzybowski JM, Kodama RM (1996) Melanomacrophage aggregations and their age relationships in the yellow mud turtle, Kinosternon flavescens (Kinosternidae). Pigment Cell Res 9:185-190

> Danscher G, Moller-Madsen B (1985) Silver amplification of mercury sulfide and selenide: a histochemical method for light and electron microscopic localization of mercury in tissue. J Histochem Cytochem 33:219-228

> Davenport J, Wrench J (1990) Metal levels in a leatherback turtle. Mar Pollut Bull 21:40-41
Deem SL, Dierenfeld ES, Sounguet GP, Alleman R and others (2006) Blood values in free-ranging nesting leatherback sea turtles (Dermochelys coriacea) on the coast of the Republic of Gabon. J Zoo Wildl Med 37: 464-471

do Vale A, Costa-Ramos C, Silva A, Silva DS, Gärtner F, dos Santos NM, Silva MT (2007) Systemic macrophage and neutrophil destruction by secondary necrosis induced by a bacterial exotoxin in a Gram-negative septicaemia. Cell Microbiol 9:988-1003

Flint M, Patterson-Kane JC, Limpus CJ, Work TM, Blair D, Mills PC (2009) Postmortem diagnostic investigation of disease in free-ranging marine turtle populations: a review of common pathologic findings and protocols. J Vet Diagn Invest 21:733-759

Godley BJ, Thompson DR, Furness RW (1999) Do heavy metal concentrations pose a threat to marine turtles from the Mediterranean Sea? Mar Pollut Bull 38:497-502

> Guirlet E, Das K, Girondot M (2008) Maternal transfer of trace elements in leatherback turtles (Dermochelys coriacea) of French Guyana. Aquat Toxicol 88:267-276

> Harris HS, Benson SR, Gilardi KV, Poppenga RH, Work TM, Dutton PH, Mazet AK (2011) Comparative health assessment of Western Pacific leatherback turtles (Dermochelys coriacea) foraging off the coast of California, 2005-2007. J Wildl Dis 47:321-337

Innis C, Merigo C, Dodge K, Tlusty M and others (2010) Health evaluation of leatherback turtles (Dermochelys coriacea) in the Northwestern Atlantic during direct capture and fisheries gear disentanglement. Chelonian Conserv Biol 9:205-222

James MC, Myers RA, Ottensmeyer CA (2005) Behaviour of leatherback sea turtles, Dermochelys coriacea, during the migratory cicle. Proc R Lond Soc B Biol Sci 272: 1547-1555

Kim HR, Kim JW, Lee MK, Kim JG (2009) Septicemia progressing to fatal hepatic dysfunction in an cirrhotic patient after oral ingestion of Photobacterium damsela: a case report. Infection 37:555-556

> Lazar B, Gracan R (2011) Ingestion of marine debris by loggerhead sea turtles, Caretta caretta, in the Adriatic Sea. Mar Pollut Bull 62:43-47

Lazar B, Lipej L, Holcer D, Onofri V and others (2008) New data on the occurrence of leatherback turtles Dermochelys coriacea in the eastern Adriatic Sea. Vie Milieu 58:237-241

Lillie RD (1954). Histopathologic technique and practical histochemistry. Blakiston Company, New York

Manfredi MT, Piccolo G, Prato F, Loria GR (1996) Parasites in Italian sea turtles. I. The leatherback turtle Dermochelys coriacea (Linnaeus, 1766). Parassitologia 38:581-583

Mrosovsky N, Ryan GD, James MC (2009) Leatherback turtles: the menace of plastic. Mar Pollut Bull 58:287-289

Obendorf DL, Carson J, McManus TJ (1987) Vibrio damsela infection in a stranded leatherback turtle (Dermochelys coriacea). J Wildl Dis 23:666-668

Orós J, Calabuig P, Déniz S (2004) Digestive pathology of sea turtles stranded in the Canary Islands between 1993 and 2001. Vet Rec 155:169-174

Orós J, Torrent A, Calabuig P, Déniz S (2005) Diseases and causes of mortality among sea turtles stranded in the Canary Islands, Spain (1998-2001). Dis Aquat Org 63: $13-24$

Rie MT, Kitana N, Lendas KA, Won SJ, Callard IP (2005) Reproductive endocrine disruption in a sentinel species 
(Chrysemys picta) on Cape Cod, Massachusetts. Arch Environ Contam Toxicol 48:217-224

Romalde JL (2002) Photobacterium damselae subsp. piscicida: an integrated view of a bacterial fish pathogen. Int Microbiol 5:3-9

Sarti Martinez AL (2000). Dermochelys coriacea. In: IUCN 2011. IUCN Red List of Threatened Species. Version 2011.1 Available at www.iucnredlist.org/apps/redlist/ details/6494/0

Spotila JR, Dunham AE, Leslie AJ, Steyermark AC, Plotkin
PT, Paladino FV (1996) Worldwide population decline of Dermochelys coriacea: are leatherback turtles going extinct? Chelonian Conserv Biol 2:209-222

Storelli MM, Storelli A, D'Addabbo R, Marano C, Bruno R, Marcotrigiano GO (2005) Trace elements in loggerhead turtles (Caretta caretta) from the eastern Mediterranean Sea: overview and evaluation. Environ Pollut 135:163-170

Threlfall W (1979) Three species of Digenea from the Atlantic leatherback turtle (Dermochelys coriacea). Can J Zool 57:1825-1829

Submitted: September 20, 2011; Accepted: May 2, 2012 Proofs received from author(s): July 6, 2012
Editorial responsibility: Andrew Cunningham,

London, UK 